\title{
IAMJ
}

INTERNATIONAL

AYURVEDIC

MEDICAL JOURNAL

ISSN: 23205091

Impact Factor: 5.344

\section{MANAGEMENT OF MALE INFERTILITY (OLIGOASTHENOZOOSPERMIA) WITH AYURVEDA}

\section{Shivani Karnwal}

Ayurveda Consultant (B.A.M.S), Department of Kayachikitsa, Patanjali Ayurved Hospital, Haridwar, Uttarakhand, India

Corresponding Author: shivanikarnwa191@gmail.com

https://doi.org/10.46607/iamj5508102020

(Published online: October 2020)

Open Access

(C) International Ayurvedic Medical Journal, India 2020

Article Received:11/09/2020 - Peer Reviewed:28/09/2020 - Accepted for Publication:05/10/2020

\section{(A) Check for updates}

\section{ABSTRACT}

Male infertility refers to a male's inability to cause pregnancy in a fertile female. There are many reasons that aid the pathology of male infertility primary includes low sperm count, volume, motility, abnormality in shapes and few reproductive dysfunctions. Oligoasthenozoopsermia which is one of the major causes behind male infertility comprises two conditions - Oligospermia (low sperm count) and Asthenozoospermia (reduced motility of sperm).Researches reveals that 1 in every 3 cases of infertility are due to the male partner so nowadays diagnosis and management of both the partners is now considered as a vital tool. In this article, I report a case of a 30 -yearold male patient with complaints of wanting an issue after a complete year of regular, unprotected intercourse. For which he had undergone all the regular diagnostic investigations of his wife, which reported no issues and recorded with regular and ovulatory cycles with patent tubes. Then progressing in the diagnosis, he had undergone a semen analysis and got diagnosed with Oligoasthenozoospermia. The issue was successfully treated with Ayurvedic drugs within a period of 1 month.

Keywords: Case study, Ayurveda, Ksheenashukra, Oligoasthenozoospermia, Male infertility 


\section{INTRODUCTION}

Male infertility is any health issue in a man that lowers the chances of his female partner getting pregnant. About 13 out of 100 couples can't get pregnant with unprotected sex. There are many causes for infertility in men and women. In over a third of infertility cases, the problem is with the man. This is most often due to problems with his sperm production or with sperm delivery. What happens under normal conditions? The man's body makes tiny cells called sperm. During sex, ejaculation normally delivers the sperm into the woman's body. The male reproductive system makes, stores, and transports sperm. Chemicals in the body called hormones control this. Sperm and male sex hormone (testosterone) are made in the 2 testicles. The testicles are in the scrotum, a sack of skin below the penis. When the sperm leave the testicles, they go into a tube behind each testicle. This tube is called the epididymis. Just before ejaculation, the sperm go from the epididymis into another set of tubes. These tubes are called the vas deferens. Each vas deferens leads from the epididymis to behind the bladder in the pelvis. There, each vas deferens joins the ejaculatory duct from the seminal vesicle. When one ejaculate, the sperm mix with fluid from the prostate and seminal vesicles. This forms semen. Semen then travels through the urethra and out of the penis.Male fertility depends on the body making normal sperm and delivering them. The sperm go into the female partner's vagina. The sperm travel through her cervix into her uterus to her fallopian tubes. There, if a sperm and egg meet, fertilization happens.The system only works when genes, hormone levels and environmental conditions are right. ${ }^{[1]}$. The most common causes of male infertility are Oligospermia (reduced number of sperm), Asthenozoospermia (reduced motility of sperm), Necrozoospermia (reduced sperm vitality), Teratozospermia (abnormal sperm morphology) and a combination of these. Vajikarana is a specialized branch of Ayurveda dealing with Shukradushti and Klaibya. Shukradushti is an acquired quantitative and qualitative abnormality in Shukra caused by faulty dietetic, psychological, traumatic factors and chronic debilitating illness due to which the individual suffers from Klaibya (Erectile dysfunction \& premature ejaculation) and there is Aharshana (decreased sexual desire). Ksheena Shukra is included in one of the varieties of Ashtavidhashukradushti. When both Vata and Pitta Dosha are vitiated, the quality and quantity of the Shukra alters and resulting into Shukradushti specially Ksheena Shukra. Ayurveda give emphasis to the treatment of Shukradushti with Dhatuvriddhikara, Balakara, Shukrajanaka and Shukrapravartaka those in-terms of increasing the sperm count and motility by using Vajeekaranadravya. ${ }^{[2]}$

\section{Case Study:}

A 30 -year-old male patient came to me on $20^{\text {th }}$ July 2020 with complaints of wanting an issue for 1 year of regular, unprotected intercourse. His past and personal history was not contributory to the present condition.

Past History: His Development of secondary sexual characters is normal. He has never suffered from any chronic medical illness, Infections (mumps orchitis, sexually transmitted infections) and genitourinary tract infections.

Treatment History:Patient was not on any treatment before.No history of any drug allergy.

Surgical History: There was no any history of surgical procedures involving the inguinal and scrotal areas (vasectomy, orchiectomy and herniorrhaphy), Drugs and environmental exposures.

Personal History: Patient is vegetarian. No history of smoking, Alcohol, Tobacco. Appetite: Good IntakeMicturition: Normal Sleep: Sound

Family History: Not specific regarding the issue.

General Examination: General Condition: Fair (Vata-Pitta), A febrileB.P:110/70 $\mathrm{mm}$ of HgPulse:74b/min.(Mandukagati)Height:165cmWeight :64kgPallor:AbsentIcterus:AbsentKoilonychia:Absent Lymphadenopathy:AbsentEdema:Absent

Ashtavidha Pariksha: Nadi: Vatapittaj (Mandooka Gati) Mutra: SamyakaMala: SamyakaJihwa: AliptaShabda: SamanyaSparsha: Samyaka Drika: Samyaka Akriti: Samyaka.

Systemic Examination: R.S.: NAD.CVS: S1S2 NCNS: Conscious, oriented. P/A-Soft, mild tenderness at lower abdomen. The physical examination 
does not show any anatomical abnormalities and there were no signs of inflammation, ulceration or rashes of testes or penis.

Investigation: Laboratory investigations show nothing abnormal. The semen analysis report (18.03.2020) presented to me on (20.07.2020) shows that the sperm count was 'few sperms to count and completely non motile spermatozoa.'

\section{Diagnosis:}

Oligoastheenozoospermia

(Ksheenashukra)

Chikitsa Upakrama: The patient was treated with Youvanamrit Vati (Divya Pharmacy), 1 tab (125mg each), ShilajitRasayan tablet (Divya Pharmacy)1 tablet (500mg each) 2 times a day with lukewarm water after meal along with Shudh Kronchbeej Churna(100gm) - 3-5 gms twice a day with milk. The treatment was continued for 1 month.
Composition of Youvanamrit Vatiand Shilajitra-

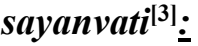

Youvanamrit Vati: Ashwagandha (Withaniasomnifera) $12 \mathrm{mg}$ Shuddha Kaunch (MucunaPruriens) $12 \mathrm{mg}$ Bala (Sida Cordifolia) 12 mgShatavari (Asparagus racemosa) $8.25 \mathrm{mg}$ Musli (Chlorophytumarundinaceum) 12mg Jaiphal (Myristicafragrans) 12 mgJavitri (Myristicafragrans) 17.5mg Shuddha Kuchla (StrychnosNux-Vomica) $2 \mathrm{mg}$ Akarkara (Anacyclus Pyrethrum) $12 \mathrm{mg}$ Babul (Acacia Arabica) $1.75 \mathrm{mg}$ Swarna Bhasma $0.25 \mathrm{mg}$ PravalPishti $0.25 \mathrm{mg}$ Vang Bhasma $5.5 \mathrm{mg}$ Makardhwaj Shuddha Shilajit $5.5 \mathrm{mg}$ Processed with PaanSwaras Excipient Gum acacia, Aerosil, Talcum QS Shilajitrasayanvati: Ashwagandha (Withaniasomnifera), Bhoomi Amla, Harad (Terminalia chebula), Baheda (Terminalia bellerica), Amla (Emblica officinalis),Aqueous extract of - Shilajit Shudha

Table 1: Post Treatment Findings: Seminal Parameters

\begin{tabular}{|l|l|l|}
\hline Parameters & $1^{\text {st }}$ Visit (20.07.2020) & $2^{\text {nd }}$ Visit $(24.08 .2020)$ \\
\hline Abstinence & 5 Days & - \\
\hline Quantity & $1.5 \mathrm{Ml}$ & - \\
\hline Colour\& Nature & Greyish White\& Viscid & Normal \\
\hline Liquefaction Time & $5 \mathrm{~min}$ & - \\
\hline Reaction & 8.0 & 7.4 \\
\hline Sperm Count Total & $30 \mathrm{million}$ & $60.8 \mathrm{million}$ \\
\hline Active Motile & $0 \%$ & $65 \%$ \\
\hline Sluggish Motile & $20 \%$ & $30 \%$ \\
\hline Non-Motile & $10 \%$ & $5 \%$ \\
\hline Abnormal Form & 80 & Not Seen \\
\hline Pus Cells & $24-25 / \mathrm{Hpf}$ & Not Seen \\
\hline
\end{tabular}

Results: After medication there is a significant upsurge in total sperm count (i.e. from 30 million to 60.8 million) with a major improvement in all the three grounds of motility where from $0 \%$ active to $65 \%$ actively motile, $20 \%$ sluggish to $30 \%$ sluggishly motile and the count of non-motile reduced to $5 \%$. The abnormal form is completely zero and the ratio of pus cells also got recovered. (Details in the above table).

\section{DISCUSSION}

This is a case study of 30-year-old male patient with the complaints of wanting an issue after a complete year of regular, unprotected intercourse. Further progressing over the investigations, he got diagnosed with Oligoasthenozoospermia. For the treatment and management, he came to my clinic. Patient came to my clinic with confirmed diagnosis of Oligoasthenozoospermia. In Ayurveda it resembles with Ksheenashukra which is due to aggravated doshas reaching male reproductive organs. According to the principles of Ayurveda, the balance of three vital energies namely Vata, Pitta and Kapha in the body is very important for maintaining the health of a body. As per this alternative therapy system, the imbalance 
of these three elements is the main reason for any ailment in the body. In Oligoasthenozoospermia both a smaller number of sperm and low motility are found. Treatment of Oligoasthenozoospermia should be aimed at to increase sperm count and motility ${ }^{[4]}$. Shukradushti is the causative factor for the infertility. Ksheenashukra is a type of shukradushti which can be correlated to Oligoasthenospermia. The treatment of Ksheenashukra mainly aims at Shukrajanaka and Shukrapravartaka in terms of increasing the sperm count and motility by using Vajeekaranadravya ${ }^{[5]}$. Ayurvedic medication like Youvanamritvati (Divya Pharmacy) and Shilajit rasayan vati has found to be very effective in such issues. Yauvanamrit Vati is a highly effective natural spermatogenetic agent. It works by increasing the secretion of testosterone, which is responsible for the spermatogenesis. It also stimulates the functions that play a role in the process of reproduction. It helps men in dealing with the problem of oligospermia and resultant infertility that mainly arise due to an inappropriate or imbalanced secretion of some hormones. It also activates the centers of reproductive functions in the brain thus allowing men to produce a stimulus needed for the reproductive functions. YauvanamritVati is revered for its ability in promoting and nourishing the aphrodisiac activity through the activation of the vital essence in the body ${ }^{[6]}$. Kaunchbeej works as an aphrodisiac and helps in increasing sexual desire. It helps to improve sperm count and motility. It also helps to increase the production and quantity of semen. Apart from this, Kaunchbeej helps reduce physiological stress and improves semen quality. This is due to its antioxidant property. Some studies state that Kaunchbeej improves sexual performance by delaying the time of ejaculation. It also improves the quality and quantity of semen because of its Guru (heavy) and Vrushya (aphrodisiac) properties. ${ }^{[7]}$. Patient responded well to this treatment. Single follow up session was done. After one month of treatment, a repeat semen analysis is done on 24/08/2020 shows completely normal semenogram. Patient feels better and overall improvement is reported within 1 month of treatment.

\section{CONCLUSION}

The drugs we used in the treatment of Ksheenashukra have the ability to promote and nourish the aphrodisiac activity and also helps in balancing of the affected doshas. Due to improved status of doshas the other action of ingredients showed increased sexual desire, improved erectile function, optimum ejaculatory function, increased frequency and a satisfactory orgasm. Thus, to conclude Oligoasthenozoospermia can be managed successfully and easily with Ayurvedic treatment and need to be studied and applied in a greater number of cases.

\section{REFERENCES}

1. https://www.urologyhealth.org/urologicconditions/male-infertility

2. Agnivesha, Charaka, Charaka Samhita with Ayurvedadipika commentary of Chakrapanidatta, edited by Vaidya YadavjiTrikamj Acharya, published byNirnaya Sagar Press, Bombay, 1941, Chikitsasthana30/135$137 ; 640$

3. Aushad Darshan published by Divya Yoga Mandir trust by Acharya Balkrishna (page 142-143).

4. Zegers-Hochschild F, Adamson GD, De Mouzon J, Ishihara O, Mansour R, et al. (2009) International Committee for Monitoring Assisted Reproductive Technology (ICMART) and the World Health Organization (WHO) revised glossary of ART terminology, 2009. Fertil Steril 92: 1520-1524

5. Sushruta Samhita of Sushruta edited by Vaidhya Jadavji Trikamji Acharya, published by Nirnaya Sagar Press, Bombay, 1941, Sharirasthana 2/3-9; 345-46

6. https://www.ayurtimes.com/divya-yauvanamrit-vatiyounamrit-vati/(Under heading 'oligospermia')

7. https://www.1mg.com/ayurveda/kaunch-beej-73

\section{Source of Support: Nil \\ Conflict of Interest: None Declared}

How to cite this URL: Shivani Karnwal: Management Of Male Infertility (Oligoasthenozoospermia) With Ayurveda. International Ayurvedic Medical Journal \{online\} 2020 \{cited October, 2020\} Available from: http://www.iamj.in/posts/images/upload/4902_4905.pdf 